Івлева С. М., старший викладач кафедри мовної та загально гуманітарної підготовки іноземців Одеський національний університет імені І. І. Мечникова

\title{
РАННІЙ П. ТИЧИНА: ІЛЮЗІЇ НАДРЕАЛЬНОСТІ
}

У статті приділено увагу сюрреалістичній образності П. Тичини на матеріалі його ранньої творчості, зокрема віршів із збірки «Сонячні кларнети». Звернуто увагу на наявність у творах експресивно вираженої емоційної тональності, надреальних алюзій, алогічних символів, автоматичної фіксації, чорного гумору.

Ключові слова: сюрреалізм, надреальні алюзї, алогічні символи, емоційна тональність.

В статье уделено внимание сюрреалистической образности П. Тычины на материале его раннего творчества, в частности стихов из сборника «Солнечные кларнетыл». Обращено внимание на наличие в произведениях экспрессивно выраженной эмочиональной тональности, надреализм аллюзий, алогичных символов, автоматической фиксации, черного юмора.

Ключевые слова: сюрреализм, надреализм аллюзий, алогичные символьл, эмочиональная тональность.

The article focuses on the surreal imagery of P. Tychyna on the material of his early work, in particular, verses from the collection «Solar Clarinet». Attention is drawn to the presence in the works of expressively expressed emotional tonality, superrealism of allusions, illogical symbols, automatic fixation, black humor.

Keywords: surrealism, suprarealism of allusions, illogical symbols, emotional tonality.

П. Тичина прийшов у літературу на зламі епох кінця XIX - початку XX століття, що був позначений усталеною ідеологією в літературі і водночас пошуками нових мистецьких засобів. На противагу теоріям віддзеркаленого зображення життя у літературі з'являються пошуки нових форм, нових моделей літературного мистецтва. Саме в цей період молодий П. Тичина «вибухнув» (С. Сфремов) першою збіркою, котра стала помітним явищем в українському літературному просторі - «Сонячні кларнети». Ця збірка вважається справжнім гімном життю, піснею радості й суму. 3 легкої руки С. Сфремова П. Тичину 
називали людиною-оркестром, котрий створив вишукану й філігранну, ніжну й тонку, барвисту й мелодійну поезію.

Визначення стильових особливостей ранньої поезії П. Тичини, зокрема на матеріалі «Сонячних кларнетів», є метою даного дослідження.

Відомо, що своїм духовним учителем поет уважав М. Коцюбинського, зустрічі з яким були для юного П. Тичини університетом. М. Коцюбинський вводив П. Тичину у світ високої літератури європейського мистецтва кінця XIX століття, що ввійшло в епоху модернізму. Нові літературно-мистецькі напрями (символізм, імпресіонізм, експресіонізм) постійно цікавили поета. Становлення індивідуальної його майстерності відбувалося й під впливом В. Винниченка, М. Жука, М. Вороного. Пошуковий настрій молодого П. Тичини відображався у зображально-виражальній майстерності й втілювався у слово. Хоча пізніше поет зрікся своїх молодих творчих пошуків. Так, у 30-ті роки в щоденникових записах П.Тичина заперечував свою причетність до символізму: «Символізм? Hi, я починав як реаліст» [Тичина 1981:64]. Але це вже був інших П. Тичина.

Дослідники не укладають характер його поезій в рамки жодного «ізму» модерністської естетики. Свій творчий стиль П. Тичина називав кларнетизмом. Деякими дослідниками рання творчість П. Тичини розуміється як «кларитичний символізм». Такі позиції з'явились у зв’язку 3 концепцію «трьох сфер» В. Стуса, котрий пояснював природу симультанної ідейно-естетичної еволюції П. Тичини поєднанням різнопланових чуттєвих поглядів. Явище кларнетизму не зустрічається в жодній літературі, окрім української і тільки в поезії П. Тичини. 3 цього приводу Ю. Ковалів писав: «Кларнетизм виявився тим містком, щуо перекидався від ідейно-естетичних, часто врізнобіч спрямованих стильових тенденцій попередніх поколінь до синтетичного типу творчості, який не вкладався у жодну стильову течію, адже органічний для П. Тичини символізм переплітався з елементами авангардизму, неоромантизму, імпресіонізму, неореалізму та необароко» [Ковалів 2003:74]. До цих 
прикінцевих стильових визначень Ю. Коваліва варто додати сюрреалізм. На наш погляд, саме сюрреалістична образність домінує у раннього П. Тичини.

Наявність сюрреалізму в українській літературі факт замовчуваний не тільки на початку XX століття, а й до сьогодення. Здебільшого сюрреалізм вважається французьким явищем, легітимність котрого пов'язана з публікацією 1924 року «Маніфесту сюрреалізму» А. Бретона. На розвиток сюрреалізму вплинуло відкриття несвідомого у психології, до якого зверталися сюрреалісти, котрі відроджували давні міфи й водночас цікавились міфотворенням нових. Сюрреалізм - явище парадоксальне i неоднозначне за своєю суттю. В українському письменстві зацікавлення сюрреалізмом з’явилось ще у повоєнний час. Зразком слугували теоретичні засади французьких сюрреалістів, хоча водночас зазнавали значної редакції, усунення надмірної агресії. У літературі ХX століття сюрреалізм не став школою - існувала лише стильова тенденція цього напряму, яка проявлялася в авторській поетиці, зокрема у раннього П. Тичини.

Наприклад, сюрреалістичного присмаку набирає образність у наступних рядках вірша-присвяти «Скорбна мати»:

Проходила по полю обніжками, межами.

Біль серце опромінив блискучими ножами!

Поглянула - скрізь тихо чийсь труп в житах чорніє...

Спросоння колосочки: ой, радуйся Маріє!

Спросоння колосочки: побудь, побудь із нами!

Спинилась божа матір, заплакала сльозами.

Автор грає словами на межі підсвідомих образів, де помітні алюзії жахливого: «блискучими ножами», «тихо чийсь труп в житах чорніє». Загальна тематика вірша «Скорботна мати» філософська. Особливість твору у тому, що автор використовує асоціативні метафори сюрреалістично наснажені й виразні: «біль серцем опромінив блискучими ножами». Система тавтологій також напружена: «зелене зеленіє», «заплакала сльозами». Помітне напруження й у створенні контрастів сюжетно-образотворчих засобів. 
У поезії «Подивилась ясно, - заспівали скрипки!» помітні вкрай напружені роздуми героя, котрі подаються в рухливих змінах. Напруження передають настрої, емоції, які змінюються один за одним: подивилась заспівали - обняла - мовчав - заспівали. Зміни руху створюють яскраву картину хвилювань на межі зриву, а перервані акорди скрипки надають додаткових ефектів надреальних подій:

Подивилась ясно, - заспівали скрипки! -

Обняла востаннє, - у мойй душі. -

Ліс мовчав у смутку, в чорному акорді.

Заспівали скрипки у моїй душі! [Тичина 2004:350].

У збірці «Сонячні кларнети»є група віршів про людське горе, спричинене Першою світовою війною: «Хтось гладив ниви...», «Іще пташки...». У них відчувається нова експресивно виражена емоційна тональність 3 присмаком надреальної образності. Поет майстерно передає найтонші настрої, почуття:

I враз - роздерлась пополам завіса! - Тиша. Мертва...

Метнувсь огонь: розцвівсь, розпавсь - аж води закипіли!

I полилася піснь, принеслась жертва.

Курять иляхи, біжать, біжать... [Тичина 2004:352].

У «Сонячних кларнетах» П. Тичина відкрив поліфонію в самому наспівному інтонаційному ладі. Специфічна властивість інтонаційної структури вірша в збірці «Сонячні кларнети» - раптові емоційні сплески в оповідному тексті (вигуки, запитання) - якесь достоту людське зітхання, спонтанний, внутрішній, незбагненний порух душі, емоційні пориви. Наприклад, у поезії «Дощ» можна помітити сюрреалістичні алюзії:

Квітчастий луг і дощуик золотий.

А в далині, мов акварелі, -

Примружились гаї, замислились оселі...

Ax, сериฺе, пий!

Повітря - мов прив'ялий трунок [Тичина 1976:248]. 
Поет у цьому вірші - споглядач первісної природи, де головну роль відіграє циклічність: весна - зародження й розквіт; зима - смерть і сон; день життя, рух; ніч - сон, статичність. Автор тонко відчуває всі грані оновлення та народження, екстравертує, знаходить і спрямовує відтінки поетичних вражень на музичність творчої напруги:

Іщее пташки в дзвінких піснях блакитний день купають,

Ще половіє золотом хвиль на сонці жита риза,

(вітри лежать, вітри на арфу грають) - а в небі свариться вже $x m o c b$.

Завіса чорно-сиза півнеба мовчки зап'яла, земля вдягає тінь.

На перший погляд вірш має поетичну легкість, але вірш ускладнюється напруженням дії, де хтось свариться, на небі чорно-сиза завіса, а земля вдягає тінь.

Навіть любовна тематика П. Тичини 3 присмаком надреальних алюзій Наприклад у вірші «Світає...»:

Проміннями схід ранить ніч, мов мечами,

Хмарки по всім небі й собі взолотіли.

Безмовні тумани тремтять над полями.

Підхоплююсь з ними я посвіжілий.

Так неспокійно автор пише про почуття.

Надреальність творчості П. Тичини - це нове світобачення у мистецтві і спосіб пізнання сфери несвідомого, божевільних станів; створення алогічних символів, автоматичної фіксації й, навіть, чорного гумору. Наприклад, як у наступних рядках:

Ріка біжить, хлюпоче, грається.

На ній міняються весни, мов убір...

Ви плачете. Вам сериее розривається:

Людина - звір [Тичина 1976:262].

Отже, в ранній поезії П. Тичини простежується наявність сюрреалістичних алюзій. Надреальна образність окремих віршів, узятих для 
аналізу, є підтвердженням головної думки цього дослідження. Однак тема сюрреалізму у творчості поета вимагає подальших грунтовних досліджень. Щоправда надреалізм у творах П. Тичини обмежується його раннім періодом.

\section{БІБЛІОГРАФІЯ}

Ковалів 2003 - Ковалів Ю. Кларнетизм Павла Тичини - нереалізована естетична концепція / Ю. Ковалів // Слово і час. - 2003. - № 1. - С. 3-8.

Косач 1947 - Косач Ю. Нотатки про сюрреалізм / Ю. Косач // Арка. 1947. - Ч. 2. - C. $14-17$.

Ожарівська 2011 - Ожарівська С. П. Сюрреалізм в українському літературному процесі кінця XX століття / С. П. Ожарівська. - Філологічні трактати. - 2011. - № 1. - С. 30-33.

Рева 2007 - Рева Л. В. Сюрреалізм в ранній поезії П. Тичини / Л. В. Рева // Філологічні науки. Збірка наукових праць. : Ч. 2. - Суми : СумДПУ імені А. С. Макаренка, 2007. - С. 229-237.

Тичина 1981 - Тичина П. Із щоденникових записів. - К. : Радянський письменник, 1981. - 430 с.

Тичина 2004 - Тичина П. Сонячні кларнети / П. Тичина. Vita Nova / А. В. Ніковський. - Фототипічне видання 1918 року. - К., 2004. - 85 с.

Тичина 1976 - Тичина П. Твори в 2-х томах / П. Тичина. - К. : Дніпро, 1976. - T. 1. -415 c.

Тичина 1976 - Тичина П. Твори в 2-х томах / П. Тичина. - К. : Дніпро, 1976. - T. 2. -423 c. 